\title{
Isolation of Dermatophytes from the Hair Coat of Healthy Persian Cats without Skin Lesions from Commercial Catteries Located in São Paulo Metropolitan Area, Brazil
}

\author{
Cayo Yuji Nitta', Alexandre Gonçalves Teixeira Daniel'2, \\ Carlos Pelleschi Taborda ${ }^{3}$, Aline Elisa Santana' \& Carlos Eduardo Larsson'
}

\begin{abstract}
Background: The study of the epidemiological chain of dermatophytosis, particularly those related to zoophilic fungi, is extremely important because of its frequent occurrence, the high infectivity of the agent, and its anthropozoonotic character. In all latitudes, asymptomatic cats are considered the main reservoirs and sources of dermatophyte infection. The study aimed to characterize the frequency of dermatophyte infection and the potential risk of microsporic infection to the owners and to possible buyers of apparently healthy Persian cats from commercial catteries of São Paulo, Brazil.

Materials, Methods \& Results: Fur samples were obtained from 61 clinically healthy Persian cats, which were devoid of typical cutaneous lesions and had negative results in Wood's lamp examination. The average age of the cats was 37.7 months; $18(29.5 \%)$ of them were males and $43(70.5 \%)$ were females. The cats were from commercial catteries located in the metropolitan region of São Paulo state capital. Samples were obtained using the technique of Mariat \& Adam using a square $\left(25 \mathrm{~cm}^{2}\right)$ of sterile carpet rubbed across the surface of the hair-coat and skin. People who had close contact with the animals were asked whether they had had typical ringworm lesions in the recent past or at the time of sample collection. The material collected was pressed onto Petri dishes containing agar supplemented with chloramphenicol and cycloheximide. The Petri dishes were handled under sterile conditions and incubated at $25^{\circ} \mathrm{C}$ for up to 21 days. There was evident fungal growth in $83.6 \%$ of the samples, and the only dermatophyte isolated was Microsporum canis. The results were analyzed using the chi-square test in order to verify possible associations between variables (sex and age range) and the frequency of dermatophyte infection in dermatologically healthy animals. However, there was no statistical difference regarding sexual predisposition $(P$ value $=0.139)$ and age $(P$ value $=0.224)$ regarding the asymptomatic dermatophyte carriers. Of the 18 people who had close contact with infected cats, eight (44.4\%) claimed to have presented with typical tinea corporis lesions in the past and three (16.7\%) said that they had such skin lesions at the time of harvest of the cat fur. There were no people who claimed to have been in contact with other species.

Discussion: In Brazil, fungal infections represent up to $8.7 \%$ of skin diseases in children, and tinea capitis caused by Microsporum canis is the most common superficial mycosis in this age group. Its interspecies transmission has been reported for decades. Approximately $50 \%$ of individuals exposed to symptomatic or asymptomatic cats acquire the disease. In up to $70 \%$ of families with infected cats, at least one family member may develop the disease. Among domestic cats, the Persian breed is most often cited as prone to spreading dermatophytes. In the study, there was fungal growth in $83.6 \%$ of the samples, and only M. canis was isolated. Among the people who had contact with the cats, $44.4 \%$ and $16.7 \%$ had typical tinea corporis lesions in the past and at the time of the interview, respectively. However, it is speculated that the rate of infection may have been higher in the humans in contact with these cats, since there may have been some hesitation and fear by the people interviewed in reporting the occurrence of characteristic skin lesions, either as a way of preserving the cattery reputation, or to spare the embarrassment in declaring oneself as infected, which is sometimes viewed negatively. The results demonstrate the potential infectivity, pathogenicity, and risk of microsporic infection in buyers of apparently healthy cats from commercial catteries located in the metropolitan region of São Paulo.
\end{abstract}

Keywords: dermatophytosis, cats, epidemiology, Persian, Microsporum canis, tinea.

${ }^{1}$ Department of Internal Medicine of the School of Veterinary Medicine and Animal Science (FMVZ-USP), University of São Paulo, São Paulo, SP, Brazil. ${ }^{2}$ School of Veterinary Medicine, Metodista University of São Paulo (UME), São Bernardo do Campo, SP. ${ }^{3}$ Microbiology Departament, Biomedical Sciences Institute (ICB), University of São Paulo (USP), São Paulo, SP. CORRESPONDENCE: C.Y. Nitta [c.nitta@uol.com.br - Fax: +55 (11) 3091-1283]. Department of Internal Medicine of the School of Veterinary Medicine and Animal Science, USP. Avenida Prof. Dr. Orlando Marques de Paiva n. 87. CEP 05508-270 São Paulo, SP, Brazil 


\section{INTRODUCTION}

The study of the epidemiological chain of dermatophytosis, particularly those related to zoophilic dermatophytes, is quite important because of its frequent occurrence, the high infectivity of the agent, and its anthropozoonotic character [21,28,54,57]. Dermatophytosis is a superficial fungal infection that affects keratinized or semi-keratinized portions of the tegument [27]. Dermatophytes are classified into three groups (zoophilic, geophilic, and anthropophilic) based on their preferred habitats [22]. In humans, $15 \%$ of cases of ringworm (tinea) are of zoonotic origin, and the vast majority of these are acquired from contact with cats $[28,52]$. Dogs and cats are considered important reservoirs and sources of dermatophyte infection for other animals and humans [3,10,40].

In all latitudes, asymptomatic cats are considered the main reservoirs and sources of dermatophyte infection, especially of Microsporum canis. Among domestic cats, the Persian breed is most often cited as prone to spreading dermatophytes [20,39,52]. Ringworm infections in domestic cats, especially asymptomatic Persian cats, are associated with their potential role as a reservoir and disseminator of zoonotic infections. This study aims to characterize the frequency of dermatophyte infection in these animals and the potential risk of infection of human contacts, including the possible buyers of apparently healthy cats from commercial catteries in São Paulo, Brazil.

\section{MATERIALS AND METHODS}

Fur samples were obtained from 61 clinically healthy Persian cats. The average age of the animals was 37.7 months, $18(29.5 \%)$ of them were males and $43(70.5 \%)$ were females. The cats came from commercial catteries located in the metropolitan region of São Paulo state capital (Latitude: $23^{\circ} 32$ ' 51' S - Longitude: $46^{\circ} 38^{\prime} 10^{\prime} \mathrm{W}$ ).

All of the owners of the catteries enrolled agreed to the inclusion of their animals in the project, and signed a consent form. There were also informed that the project (No. 2764/2012) was in line with the ethical principles of animal experimentation established by the Ethics Commission on Animal Use (CEUA), Faculty of Veterinary Medicine and Animal Science, University of São Paulo (USP-FMVZ).

During the examination, the owners were asked whether they or other people in close contact with the cats had presented with skin lesions (with or without pruritus, alopecia, dyschromia, crust of distinct configurations, etc.) suggestive of dermatophyte infection in the last 90 days or at the time of visit to the property.

The animals were previously identified and subjected to anamnesis and the following examinations: physical, otologic, and dermatologic, including the Wood's lamp examination. Only animals devoid of soft tissue injuries, negative to the Wood's lamp examination, and without apparent systemic disease were included in the study. Samples were obtained using the technique of Mariat \& Adam [34] using a square $(25 \mathrm{~cm} 2)$ of sterile carpet rubbed across the skin and hair coat surface.

After harvesting, the squares of sterile carpet were rewrapped in the original aluminized envelope, and, within $24 \mathrm{~h}$, sent to the Dimorphic Pathogenic Fungi Laboratory of the Institute of Biomedical Sciences in the University of São Paulo (ICB-USP). The carpets were pressed onto Petri dishes, which contained Sabouraud agar supplemented with chloramphenicol $(0.05 \mathrm{mg} / \mathrm{mL})$ and cycloheximide $(0.4 \mathrm{mg} / \mathrm{mL})$ $\left[\mathrm{Mycosel}^{\mathrm{TM}}\right.$ Agar BBL ${ }^{\mathrm{TM}}$ ], under sterile conditions and incubated at $25^{\circ} \mathrm{C}$ for up to 21 days.

Identification of dermatophytes was performed by macroscopic analysis of the morphology of the colonies and microscopic observation of the macroconidia. In cases when identification by both colony morphology and macroconidia characteristics was inconclusive, the giant colony technique followed by microscopic examination by morphological microcultivation in blade was performed $[11,27]$.

\section{Statistical analysis}

Statistical analysis was performed using Minitab software, version 16 , with a $P$ value $<0.05$. The results were analyzed using the chi-square test in order to verify possible associations between variables (sex and age range) and the frequency of dermatophytes isolated in dermatologically healthy animals.

\section{RESULTS}

Of the 61 apparently healthy cats, as assessed by physical and otodermatologic examination, 51 $(83.6 \%)$ were positive for mycological growth from the hair coat, which is characteristic of asymptomatic carriers. No dermatophytes were isolated from the hair coats of the remaining 10 healthy cats (nine females and one male). 
Microsporum canis was the only fungal species isolated. Of the 18 owners or other human contacts of the mycologically positive cats, eight $(44.4 \%)$ had already presented, according to their own reports, with typical lesions of ringworm (tinea corporis) and three $(16.7 \%)$ had typical skin lesions at the time of sample collection from the cats. There were no people who claimed to have been in contact to other species. We did not observe a statistically significant difference $(P$ value $=0.139$ ) between the sexes of asymptomatic fungal spore carriers. There was no statistically significant difference $(P$ value $=0.224)$ between the ages of the asymptomatic carriers.

\section{DISCUSSION}

In dermatology, epidemiological surveys indicate that mycoses are among the most common zoonoses [16,37]. They are considered the third most frequent skin disease in children up to 12 years old and one of the most prevalent ones in the adult population $[25,43]$.

In Brazil, fungal infections can represent up to $8.7 \%$ of skin diseases in children [44], and tinea capitis caused by Microsporum canis is the most common superficial mycosis in this age group $[5,17,19,49]$. Interspecies transmission has been reported for decades $[46,57,52]$. In humans, $15 \%$ of cases of ringworm infections (tinea) are of zoonotic origin, and the vast majority of these are acquired from contact with cats $[26,28,47,52]$.

The information collected from human contacts from the catteries included in this study revealed that more than $40 \%$ of these people had had dermatophytic skin lesions previously, and another $16 \%$ had evolving dermatophytic lesions at the time of the interview. These percentages characterize the infectivity and pathogenicity of Microsporum canis for infected contacts and even more for susceptible individuals $[37,39]$. However, it is speculated that a higher percentage of infection in human contacts may exist, since there may have been some hesitation and fear by the people interviewed in referring to the occurrence of characteristic skin lesions, either as a way to preserve the cattery reputation, or to spare the embarrassment in declaring oneself as infected.

The percentages herein disclosed are consistent with the vast majority of published studies. Approximately $50 \%$ of the people exposed to infected, symptomatic or asymptomatic, cats acquire the disease. Moreover, between $30 \%$ and $70 \%$ of families with infected cats may have at least one family member that develops the disease [46,52]. In Europe, $M$. canis was isolated in $53.6 \%$ and $36.4 \%$ of asymptomatic cats and dogs, respectively, who lived with owners diagnosed with tinea corporis [10].

Studies in Brazil $[7,48]$ involving dogs and cats and their owners affected by dermatophytosis found that $34.2 \%$ to $66.7 \%$ of cats or dogs were positive for dermatophytes, and the fungus $M$. canis was the most prevalent. A high correlation between infected owners and the presence of canine and feline contacts was observed [49].

Many apparently healthy animals, free of soft tissue injuries, can be dermatophyte carriers. Numerous published studies support this assertion $[40,52,54,55]$. Table 1 shows a compilation of investigation results regarding cats devoid of skin lesions that were eventually found to be carriers of dermatophytes. In Brazil, it is assumed that between $8.4 \%$ and $30 \%$ of the feline population carries dermatophytes without exhibiting obvious skin lesions $[13,18,21,30]$.

In this study, all samples were obtained from animals from commercial catteries in São Paulo. The percentage of occurrence of dermatophytes in asymptomatic Persian cats was $83.5 \%$. The high prevalence of asymptomatic carriers of dermatophytes, as evidenced in this study, can presumably be related to strains of low virulence perpetuated in these commercial catteries. The enzymatic activity of keratinophilic fungi such as Microsporum canis is cited as an important virulence factor of dermatophytes and may be related to the variability in clinical presentation and the prevalence of dermatophytosis [23,33,36,56].

The zoophilic fungus $M$. canis was the single agent isolated from the samples of this study, corroborating with the available literature. Absence of Trichophyton spp. and M. gypseum in the samples may be related to limited contact of the enrolled cats with the typical reservoir hosts and with environments contaminated by these fungi $[4,8,21,41,50,58,59]$. There was no statistical association of sex or age with the predisposition to the infection, although previous reports in literature indicate greater predisposition for young animals and males $[2,9,54]$. 
Table 1. Compiled results of past investigations involving cats without skin lesions, by geographical location, percentage of carrier animals and dermatophyte species in the world.

\begin{tabular}{|c|c|c|c|c|c|}
\hline Continent & Author/year & Country & Sample & $\begin{array}{l}\text { Asymptomatic } \\
\text { carriers }(\%)\end{array}$ & Dermatophyte (\%) \\
\hline \multirow{8}{*}{ America } & Zaror et al. (1985) & Brazil & 104 & 88,5 & $88,5 \% \mathrm{MC}$ \\
\hline & Ferreiro et al. (2014) & Brazil & 191 & 8,4 & $5,8 \% \mathrm{MC} ; 2,6 \% \mathrm{MG}$ \\
\hline & Lima et al. (2016) & Brazil & 50 & 22 & $\#$ \\
\hline & Moriello \& deboer (1991) & United States & 172 & 9,3 & $87,5 \% \mathrm{TR}$ \\
\hline & Boyanowski et al. (2000) & United States & 200 & 5,5 & $91 \% \mathrm{MC} ; 1 \% \mathrm{TM}$ \\
\hline & López-martinez (1986) & Mexico & 100 & 26,0 & $100 \% \mathrm{MC}$ \\
\hline & López et al. (2012) & Argentina & 37 & 10,8 & $* * *$ \\
\hline & Betancourt et al. (2009) & Chile & 50 & $* * *$ & $60 \%$ M.C \\
\hline \multirow{6}{*}{ Europe } & Cafarchia et al. (2006) & Italy & 248 & 28,2 & $23.4 \% \mathrm{MC} ; 2.4 \% \mathrm{TT} ; 1.6 \% \mathrm{MG} ; 0.8 \% \mathrm{TA}$ \\
\hline & Romano et al. (1997) & Italy & 173 & 49,7 & $85,4 \% \mathrm{MC} ; 3,5 \% \mathrm{TM} ; 1,2 \% \mathrm{MG}$ \\
\hline & Duarte et al. (2010) & Portugal & 136 & 29,5 & $42,5 \% \mathrm{MC} ; 37,5 \% \% \mathrm{TM} ; 20 \% \mathrm{TV}$ \\
\hline & Sparkes et al. (1994 & United Kingdom & 181 & 2,2 & $100 \% \mathrm{MC}$ \\
\hline & Quaife \& Womar (1982) & United Kingdom & 45 & 36,0 & $100 \% \mathrm{MC}$ \\
\hline & Patel et al. (2005) & United Kingdom & 169 & 5,3 & $3,3 \% \mathrm{MC} ; 3,3 \% \mathrm{TM} ; 22,2 \% \mathrm{TT}$ \\
\hline \multirow{2}{*}{ Oceania } & Baxter (1973) & New Zealand & 200 & 39,0 & $92 \% \mathrm{MC}$ \\
\hline & Woodgyer (1977) & New Zealand & 199 & 19,0 & 6,55 MC; 7,5\% TT; 2,5\% TA; 2,5\% MK \\
\hline \multirow{3}{*}{ Asia } & Ilhan et al. (2016) & Turkey & 264 & 7,1 & $4.1 \% \mathrm{TT} ; 1.1 \% \mathrm{TG} ; 1.1 \% \mathrm{MN} ; 0.7 \% \mathrm{Tm}$ \\
\hline & Alpun \& Ozgur (2009) & Turkey & 100 & 11 & $100 \% \mathrm{MC}$ \\
\hline & Shokohi \& Naseri (2006) & Iran & 100 & 4,0 & $75 \% \mathrm{MG} ; 25 \% \mathrm{TM}$ \\
\hline
\end{tabular}

\#Not informed. $\mathrm{MG}=$ Microsporum gypseum; $\mathrm{MC}=$ Microsporum canis; $\mathrm{MK}=$ Microsporum cookei; $\mathrm{MN}=$ Microsporum nanum; $\mathrm{TR}=$ Trichophyton rubrum $; \mathrm{TM}=$ Trichophyton mentagrophytes; $\mathrm{TV}=$ Trichophyton verrucosum; $\mathrm{TA}=$ Trichophyton ajelloi; $\mathrm{TT}=$ Trichophyton terrestre.

Unusually, there is no information available in the literature regarding only Persian cats as asymptomatic carriers, which limits the comparison with the results obtained in this study.

Among domestic cats, the Persian breed is most often cited as prone to spread dermatophytes. Several hypotheses were formulated to explain this predisposition. Among these, it was suggested that the extremely long and abundant hair coat, genetic factors, and intrinsic characteristics of the fungi may be involved $[2,34,37]$. The typical long hair coat of Persian cats may predispose them to fungal infection since the fungal propagules would be able to stay in the fur more easily, thus remaining much more protected from mechanical removal during licking $[2,29,39,50,54]$.

In one of the few existing studies involving only exposition cats, considering those as fully racially defined, developed by British researchers [50], it was reported that $35 \%$ of the cats with long hair coat were carriers of Microsporum canis. The study does not refer to the total number of animals evaluated, but in all 22 cats with short hair coats, no dermatophytes were isolated. The authors suggested that the higher predisposition of long hair coat cats to the infection is associated with conditions of creation and management, and that it is possible that excessive combing and brushing of the fur of these exposition animals may produce an electrostatic effect with an electric charge buildup that would attract arthrospores from environmental fungi and other felines. Given that these animals usually live among other cats and are often taken to exhibitions, some authors add that this contact with other felines could be a reason why a highly infectious agent such as Microsporum canis could easily disseminate [54].

Animals kept in shelters or commercial catteries are cited as more prone to being asymptomatic carriers of ringworm because of the environment and sanitary management [35]. The stress due to the high population density, pregnancies, successive lactations, 
and frequent participation in exhibitions is also a predisposing factor $[50,52]$.

Under stressful conditions, cats are known to reduce the innate behavior of self-cleaning by licking, thus decreasing the mechanical removal of arthroconidia and restricting the distribution of sebaceous material, and limiting the action of its known properties [12,13,41,42].

\section{CONCLUSION}

Fungal growth was evident in $51(83.5 \%)$ of the Persian cats, and only Microsporum canis was isolated. Among the human contacts, $8(44.4 \%)$ and 3 $(16.7 \%)$ had experienced in the past or had presumptive tinea corporis lesions during the sample collection, respectively.

Therefore, there is a high possibility of ringworm transmission to humans and animals exposed to the source of infection, such as cats purchased from such catteries, especially when these are introduced into the property without prior submission to physical and other examinations.

\section{MANUFACTURER}

${ }^{1}$ Becton, Dickinson and Co. Sparks, MD, USA.

Funding. Processo: 2012/11048-1. Fundação de Amparo à Pesquisa do Estado de São Paulo (FAPESP).

Ethical approval. The project (No. 2764/2012) was in line with the ethical principles of animal experimentation established by the Ethics Commission on Animal Use (CEUA), Faculty of Veterinary Medicine and Animal Science, University of São Paulo (USP-FMVZ)

Declaration of interest. The authors report no conflicts of interest. The authors alone are responsible for the content and writing of the paper.

\section{REFERENCES}

1 Alpun G. \& Ozgur N.Y. 2009. Mycological examination of Microsporum canis infection in suspected dermatophytosis of owned and ownerless cats and its asymptomatic carriage. Journal of Animal and Veterinary Advances. 8(4): 803-806.

2 Balda A.C., Larsson C.E, Otsuka M. \& Gambale W. 2004. Estudo retrospectivo de casuística das dermatofitoses em cães e gatos atendidos no serviço de dermatologia da Faculdade de Medicina Veterinária e Zootecnia da Universidade de São Paulo. Acta Scientiae Veterinariae. 32(2): 133-140.

3 Bassanesi M.C., Conci L.A., Souza A.P. \& Severo L.C. 1993. Fonte de infecção na dermatofitose por Microsporum canis. Anais Brasileiros de Dermatologia. 68(1): 11-13.

4 Baxter M. 1973. Ringworm due to Microsporum canis in cats and dogs in New Zealand. New Zealand Veterinary Journal. 21(3): 33-37.

5 Bertanha F., Nelumba E.J.P., Freiberg A.K., Samorano L.P. \& Festa Neto C. 2016. Profile of patients admitted to a triage dermatology clinic at a tertiary hospital in São Paulo, Brazil. Anais Brasileiros de Dermatologia. 91(3): 318-325.

6 Betancourt O., Salas V., Otarola A., Zaror L., Salas E. \& Neumann, J. 2009. Microsporum canis on dermatologically healthy cats in Temuco city, Chile. Revista Iberoamericana de Micología. 26 (3): 206-210.

7 Bier D., Farias M., Muro M., Soni L., Carvalho V. \& Pimpão C. 2012. Isolamento de dermatófitos do pelo de cães e gatos pertencentes a proprietários com diagnóstico de dermatofitose. Archives of Veterinary Science. 18(1): 1-8.

8 Boyanowski K.J., Ihrke P.J., Moriello K.A. \& Kass P.H. 2000. Isolation of fungal flora from the hair coats of shelter cats in the Pacific coastal USA. Veterinary Dermatology. 11(2): 143-150.

9 Cabañes F.J., Abarca M.L., Bragulat M.R. \& Castellá G. 1996. Seasonal study of the fungal biota of the fur of dogs. Mycopathologia. 133(1): 1-7.

10 Cafarchia C., Romito D., Capelli G., Guillot J. \& Otranto D. 2006. Isolation of Microsporum canis from the hair coat of pet dogs and cats belonging to owners diagnosed with M. canis tinea corporis. European Society of Veterinary Dermatology. 17(5): 327-331.

11 Carlotti D.N. 1997. Canine and feline superficial fungal skin infections. Veterinary Quarterfly. 19(1): 45-46.

12 Carlotti D.N., Guinot P., Meissonnier E. \& Germain P. 2010. Eradication of feline dermatophytosis in a shelter: a field study. Veterinary Dermatology. 21(3): 259-266.

13 Deboer D.J. \& Moriello K.A. 1994. Development of an experimental model of Microsporum canis infection in cats. Veterinary Microbiology. 42(4): 289-295.

14 Dieckmann A.M., Quevedo A.C., Ribeiro V.L.S. \& Castro M.C.N. 1998. Dermatófitos isolados de caninos e felinos clinicamente sadios procedentes da cidade de Niterói, RJ, Brasil. Revista Brasileira de Ciência Veterinária. 5(2): 93-94. 
15 Duarte A., Castro I., Pereira da Fonseca I.M., Almeida V., Madeira de Carvalho L.M., Meireles J., Fazendeiro M.I., Tavares L. \& Vaz Y. 2010. Survey of infectious and parasitic diseases in stray cats at the Lisbon Metropolitan Area, Portugal. Journal of Feline Medicine \& Surgery. 12(6): 441-446.

16 d'Ovidio D. \& Santoro D. 2015. Survey of Zoonotic Dermatoses in Client-Owned Exotic Pet Mammals in Southern Italy. Zoonoses Public Health. 62(2): 100-104.

17 Fernandes N.C., Akiti T. \& Barreiros M.G.C. 2001. Dermatophytoses in children: study of 137 cases. Revista do Instituto de Medicina Tropical de São Paulo. 43(2): 83-85.

18 Ferreiro L., Roehe C., Dorneles A.S., Machado G., Fraga C.F., Lupion C.G., Barroso G.J. \& Sanches E.M.C. 2014. Isolamento de dermatófitos e fungos saprotróficos do pelame de gatos sem dermatoses na região metropolitana de Porto Alegre - RS, Brasil. Acta Scientiae Veterinariae. 42: 1191.

19 Filho S.T., Cucé L.C., Foss N.T., Marques S.A. \& Santamaria J.R. 1998. Efficacy, safety and tolerability of terbinafine for Tinea capitis in children: Brazilian multicentric study with daily oral tablets for 1, 2 and 4 weeks. Journal of the European Academy of Dermatology and Venereology. 11(2): 141-146.

20 Frymus T., Gruffydd-Jones T., Pennisi M.G., Addie D., Belák S., Boucraut-Baralon C., Egberink H., Hartmann K., Hosie M.J., Lloret A., Lutz H., Marsilio F., Möstl K., Radford A.D., Thiry E., Truyen U. \& Horzinek M.C. 2013. Dermatophytosis in cats: $\mathrm{ABCD}$ guidelines on prevention and management. Journal of feline medicine and surgery. 15(7): 598-604.

21 Gambale W., Correa B., Paul C.R. Purchio A. \& Larsson C.E. 1987. Ocorrência de fungos em lesões superficiais de cães na cidade de São Paulo, Brasil. Revista da Faculdade de Medicina Veterinária e Zootecnia da Universidade de São Paulo. 24: 187-192.

22 Georg L.K. 1954. Animal Ringworm in Public Health. Dermatophytes: New methods in classification. Atlanta, GA, US. Public Health Service. 31-36.

23 Grappel S.F \& Blank F. 1972. Role of keratinase in dermatophytosis. I. Immune responses of guinea pigs infected with Trichophyton mentagrophytes and guinea pigs immunized with keratinases. Dermatologica. 145(4): 245-255.

24 Ilhan Z., Karaca M., Ekin I.H., Solmaz H., Akkan H.A. \& Tutuncu M. 2016. Detection of seasonal asymptomatic dermatophytes in Van cats. Brazilian Journal of Microbiology. 47(1): 225-230.

25 Kakande B., Gumedze F., Hlela C. \& Khumalo N.P. 2016. Focus on the Top Ten Diagnoses Could Reduce Pediatric Dermatology Referrals. Pediatric Dermatology. 33(1): 99-102.

26 Kaplan W. 1967. Epidemiology and public health significance of ringworm in animals. Archives of Dermatology. 96(4): 404-408.

27 Lacaz C.S., Porto E., Martins J.E.C., Heins-Vaccari E.M. \& Melo N.T. 2002. Micoses superficiais. In: Tratado de Micologia Médica Lacaz. 9.ed. São Paulo: Sarvier, pp.252-340.

28 Larsson C.E., Lucas R. \& Germano P.M.L. 1997. Dermatofitoses de cães e gatos em São Paulo: estudo da possível influência sazonal. Anais Brasileiros de Dermatologia. 72(2): 139-142.

29 Lewis D.T., Foil C.S. \& Hosgood G. 1991. Epidemiology and Clinical Features of Dermatophytosis in Dogs and Cats at Louisiana State University: 1981-1990. Veterinary Dermatology. 2(2): 53-58.

30 Lima S.R., Silva W.A., Silveira M.M., Neves R.C.S.M., Dutra V. \& Sousa V.R.F. 2016. Isolamento de dermatófitos em 50 felinos assintomáticos atendidos no HOVET-UFMT, em Cuiabá. Semina: Ciências Agrárias, Londrina. 37(4): 2003-2008.

31 Lopez M.F., Grilli D., Degarbo S., Arenas G. \& Telechea A. 2012. Frequency of dermatophytes in a sample of cats in the urban area of Gran Mendoza, Argentina. Revista Iberoamericana de Micología. 29(4): 238-240.

32 López Martínez R. 1986. Investigación de algunas fuentes de infección en las dermatofitosis: estudio de suelos, animales y hombre. Gaceta Médica de México. 122(5/6): 167-172.

33 Mancianti F., Nardoni S., Corazza M., D’Achille P. \& Ponticelli C. 2003. Environmental detection of Microsporum canis arthrospores in the households of infected cats and dogs. Journal of Feline Medicine and Surgery. 5(6): 323-328.

34 Mariat F. \& Adan-Campos C. 1967. La téchnique du carré de tapis, méthode simple de prélèvement dans les mycoses superficielles. Annales de l'Institut Pasteur. 113: 666-668.

35 Mignon B.R. \& Losson B. 1997. Prevalence and characterization of Microsporum canis carriage in cats. Journal of Medical \& Veterinary Mycology. 35(4): 249-256.

36 Morganti L., Tampieri M.P., Galuppi R. \& Menegali F. 1992. Morphological and biochemical variability of Microsporum canis strains. European Journal of Epidemiology. 8(3): 340-345. 
37 Moriello K.A. 2003. Important factors in the pathogenesis of feline dermatophytosis. Veterinary Medicine. 98(3): 845-858.

38 Moriello K.A. 2004. Treatment of dermatophytosis in dogs and cats: review of published studies. Veterinary Dermatology. 15(2): 99-107.

39 Moriello K. 2014. Feline dermatophytosis: aspects pertinent to disease management in single and multiple cat situations. Journal of Feline Medicine and Surgery. 16(5):419-431.

40 Moriello K.A. \& Deboer D.J. 1991. Fungal flora of the haircoat of cats with and without dermatophytosis. Journal of Medical and Veterinary Mycology. 29: 285-92.

41 Moriello K.A., Kunkle G. \& Deboer D.J. 1994. Isolation of Dermatophytes from the Haircoats of Stray Cats from Selected Animal Shelters in two Different Geographic Regions in the United States. Veterinary Dermatology. 5: 57-62.

42 Moriello K.A. \& Newbury S. 2006. Recommendations for the management and treatment of dermatophytosis in animal shelters. Veterinary Clinics of North America Small Animal Practice. 36(1): 89-114.

43 Murray P.R., Drew W.L. \& Korbay J.G.S. 1994. Superficial, Cutaneous, and Subcutaneous Mycoses. In: Medical Microbiology. 5th edn. St. Louis: Mosby Co., pp.404-437.

44 Oliveira J.A.A., Barros J.A., Cortez A.C.A. \& Oliveira J.S.R.L. 2006. Micoses superficiais na cidade de Manaus, AM, entre março e novembro/2003. Anais Brasileiros de Dermatologia. 81(3): 238-243.

45 Patel A., Lloyd D.H. \& Lamport A.I. 2005. Survey of dermatophytes on clinically normal cats in the southeast of England. Journal of Small Animal Practice. 46(9): 436-439.

46 Pepin G.A. \& Oxenham M. 1986. Zoonotic dermatophytosis (ringworm). Veterinary Record. 118(4): 110-111.

47 Pier A.C., Smith J.M.B., Alexiou H., Ellis D.H., Lund A. \& Pritchard R.C. 1994. Animal ringworm - its aetiology, public health significance and control. Journal of Medical and Veterinary Mycology. 32(1): 133-150.

48 Pinheiro A.Q., Moreira J.L.B. \& Sidrim J.J.C. 1997. Dermatofitoses no meio urbano e a coexistência do homem com cães e gatos. Revista da Sociedade Brasileira de Medicina Tropical. 30(4): 287-294.

49 Pires C.A., Cruz N.F., Lobato A.M., Sousa P.O., Carneiro F.R. \& Mendes A.M. 2014. Clinical, epidemiological, and therapeutic profile of dermatophytosis. Anais Brasileiros de Dermatologia. 89(2): 259-264.

50 Quaife R.A. \& Womar S.M. 1982. Microsporum canis isolations from show cats. Veterinary Record. 110(14): 333334.

51 Romano C., Valenti L. \& Barbara R. 1997. Dermatophytes isolated from asymptomatic stray cats. Mycoses. 40(1112): 471-472.

52 Miller W.H., Griffin C.E., Campbell K.L. \& Muller G.H. 2013. Fungal skin diseases. In: Muller and Kirk's Small Animal Dermatology. 7th edn. St. Louis: Elsevier Health Sciences, pp.223-283.

53 Shokohi T. \& Naseri H. R. 2006. Cutaneous fungal flora in asymptomatic stray cats in the north of Iran. Journal of Animal and Veterinary Advances. 5(5): 350-355.

54 Sparkes A.H., Gruffydd-Jones T.J., Shaw S.E., Wright A.I. \& Stokes C.R. 1993. Epidemiological and diagnostic features of canine and feline dermatophytosis in the United Kingdom from 1956 to 1991. Veterinary Record. 133(3): $57-61$.

55 Thomas M.L.E., Scheidt V.J. \& Walker R.L. 1989. Inapparent carriage of Microsporum canis in cats. The Compendium of Continuing Education for the Practicing Veterinarian. 11(5): 563-570.

56 Viani F.C., Dos Santos J.I., Paula C.R., Larson C.E. \& Gambale W. 2001. Production of extracellular enzymes by Microsporum canis and their role in its virulence. Medical Mycology. 39(5): 463-468.

57 Wright A.I. 1989. Ringworm in dogs and cats. Journal of Small Animal Practice. 30: 242-249

58 Woodgyer A.J. 1977. Asymptomatic carriage of dermatophytes by cats. New Zealand Veterinary Journal. 25(3): 67-69.

59 Zaror L., Fischmann O., Borges M., Vilanova A. \& Levites J. 1986. The role of cats and dogs in the epidemiological cycle of Microsporum canis. Mykosen. 29(4): 185-188. 